\title{
Sofrer e sorrir - cantar: os sambas de Bide e Marçal
}

\author{
[ Suffering and smiling - singing: Bide e Marçal's sambas
}

\author{
Cláudia Neiva de Matos ${ }^{\mathrm{I}}$
}

Trabalho apoiado por bolsa de pesquisa do CNPq.

\begin{abstract}
RESUMO - O trabalho discute a articulação ambivalente entre alegria e tristeza, característica de algumas vertentes da poética do samba e apontada em discursos críticos e jornalísticos sobre o gênero. Bastante comum nos sambas das décadas de I930 e I940, a conjunção entre chorar e cantar, sofrer e sambar manifesta-se nas letras, mas também na estrutura integral das obras, incluindo música e performance. Uma letra queixosa pode unir-se a uma melodia animada, incluindo sugestões variadas e mesmo contrastivas que vêm da interpretação vocal e do acompanhamento instrumental. Para pesquisar esses procedimentos e efeitos no corpo das obras, o trabalho elege o repertório composto, entre I933 e I947, pelos parceiros Alcebíades Barcelos e Armando Marçal, uma das mais constantes e produtivas duplas de compositores da música popular brasileira. • PALAVRAS-CHAVE -Samba; Bide e Marçal; letra
\end{abstract}

\begin{abstract}
e melodia. ABSTRACT - This article discusses the ambivalent articulation between joy and sadness, characteristic of some strands of the samba poetics and pointed out in critical and journalistic discourses about the genre. Quite common in sambas of the I930s and I940s, the conjunction of crying and singing, suffering and dancing the samba, can be found in the lyrics, but also in the whole structure of the songs, which includes music and performance. A complaining lyrics can be combined with an animated melody, in addition to the varied and even contrastive suggestions coming from vocal and instrumental performance. To study these procedures and effects by analysing a corpus of sambas, I take the repertoire composed, between I933 and I947, by Alcebíades Barcelos and Armando Marçal, one of the most constant and productive associations of songwriters in Brazilian popular music. • KEYWORDS · Samba; Bide and Marçal; lyrics and melody.
\end{abstract}

Recebido em 8 de novembro de 2017

Aprovado em 22 de julho de 2018

MATOS, Cláudia Neiva de. Sofrer e sorrir - cantar: os sambas de Bide e Marçal. Revista do Instituto de Estudos Brasileiros, Brasil, n. 70, p. 2I-43, ago. 2018.

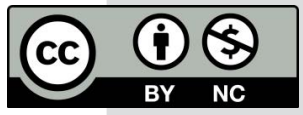

DOI: http://dx.doi.org/ro.II6o6/issn.23I6-90IX.voi70p2I-43

I Universidade Federal Fluminense (UFF, Niterói, RJ, Brasil). 
A própria dor é uma felicidade.

(Mário de Andrade)

Não podendo revelar os mistérios da criação só nos resta valorizá-los, distinguindo-os cada vez mais daquilo que não tem mistério.

(Luiz Tatit)

\section{Paradoxos da Alegria do samba}

Em março de 20I7, no fórum cibernético da Seção Latino-americana da International Association for Studies of Popular Music (IASPM-AL), a musicóloga argentina Berenice Corti levantou a questão dos "paradoxos da Alegria do Samba". Nesse âmbito apontou três tópicos do seu particular interesse, dos quais dois diretamente relativos ao carnaval: "el Samba de enredo como expresión carnavalesca en donde se relaten historias dramáticas o trágicas" e "el carnaval como expresión, en algún sentido, de experiencias de sufrimiento (esclavización, explotación)" (CORTI, 20I7). Ligados entre si, esses dois tópicos remetem para a feição negra e proletária do samba, suas origens étnicas e sociais, a história de infortúnios e violências que lhe marcaram a temática e a poética.

O terceiro tópico (na verdade, o primeiro na lista) destacado por Berenice Corti (20I7) foi a ocorrência, no samba, de "letras tristes y melancólicas en músicas 'alegres". Aqui a observação desloca-se do sentido referencial e sócio-histórico do gênero para a própria estrutura estética de sua linguagem; e o repertório em foco transcende o carnaval e o samba-enredo (que estavam no núcleo dos dois primeiros tópicos) para abarcar uma extensa gama dos chamados sambas de meio-de-ano.

Respondendo a Berenice, outro pesquisador da IASPM-AL, Tiaraju Dandrea, focalizou também as origens sócio-históricas do gênero, buscando a chave da questão na "histórica unión del samba, de princípio un canto triste y de lamento, con una fiesta europea cuyo eje seria la alegria o el brindis, llamada carnaval. Cuantas paradojas este encuentro histórico habrá producido y sigue produciendo?" (DANDREA, 2OI7).

Apesar de ter suscitado poucas reações na lista de discussões da IASPM-AL (talvez devido à escassa participação de pesquisadores brasileiros), a questão levantada por 
Berenice tem seu interesse e pertinência atestados pela frequência com que sempre aflorou na própria letrística do samba, nas narrativas jornalísticas a seu respeito e, ainda que não se possa apontar um trabalho específico de porte sobre o tema, em estudos acadêmicos de diversas áreas ${ }^{2}$. A acomodação do sofrimento com a alegria é ademais um tópico costumeiro na cultura brasileira em geral e na reflexão sobre essa cultura. No campo do samba, ele encontra talvez sua mais intensa e fluente representação.

Até o início do século XX, os discursos (literários, históricos, críticos, artísticos) sobre a cultura brasileira mostravam-na, em geral, dominada pelas marcas da melancolia, da saudade, do exílio. Essa tristeza era frequentemente contrastada pelo belo vigor da natureza tropical, como na abertura do Retrato do Brasil de Paulo Prado: "Numa terra radiosa vive um povo triste". Segundo o autor, o principal culpado por isso seria o colonizador português, cobiçoso e lúbrico: "Legaram [à terra] essa melancolia os descobridores que a revelaram ao mundo e a povoaram" (PRADO, I98I, p. I7). O livro de Prado, cujo subtítulo é "Ensaio sobre a tristeza brasileira”, foi lançado em I928. O autor, no entanto, pertencia ao grupo de intelectuais e artistas ligados ao Modernismo. E o movimento de I922 trouxera uma proposta inteiramente diversa de conceber o Brasil, na qual a alegria é que era "a prova dos nove" (ANDRADE, I976). A vocação para a festa, o riso e o gozo era associada principalmente às genealogias secundarizadas por Paulo Prado: índios e negros. Também no Macunaíma de Mário de Andrade (I973), do mesmo ano de I928, o banzo malemolente do herói é todo o tempo sacudido pelos gestos lúdicos e pelo humor. A sensualidade, que em Paulo Prado motiva o abatimento emocional, é nos poetas modernistas um fator de alegria.

Em “Lágrimas no País do Carnaval: melancolia e música popular no Brasil”, Allan de Paula Oliveira comenta a dominância do veio melancólico na cultura brasileira (OLIVEIRA, 20I4, p. 8). Para o autor, o Modernismo seria responsável pela novidade de um relevo inusual assumido pelo humor, a contrapelo de uma tradição lírica centralizada no desalento, em suas expressões românticas e simbolistas ou parnasianas.

\section{FLOR AMOROSA DE TRÊS RAÇAS TRISTES}

Cinco anos antes da Semana de Arte Moderna, em I9I7, o renomado poeta parnasiano Olavo Bilac (I9I9) publicava um soneto intitulado "Música brasileira". A partir de imagens candentes de sensualidade (o ritmo, a dança, o pecado, o feitiço), o poema vai em seguida dobrar-se ao peso da "tristeza/ dos desertos, das matas e do oceano". Aqui, os cenários naturais não figuram a natureza brasileira em si, e sim remetem aos três grupos etnoculturais que formaram a população do país: respectivamente, africanos cativos, nativos indígenas e colonizadores europeus. O poema evoca uma história de perdas e desterros que reúne os povos dominante e dominados num estranho destino comum de infortúnio. A articulação de imagens postas em analogia resulta numa figura idealmente integrada, onde diferenças e conflitos são resolvidos e silenciados

2 Aqui vai um pequeno exemplo: "Ao tratar a dor e o sofrimento com ternura, o sambista faz alianças com o devir e exprime uma discreta alegria da potência de resistir. Ele diz 'não' à exposição excessiva ao sofrimento e, também, à política do ‘evitamento da dor' que despotencializa a vida” (BARCELOS, 20Io, p. I7). 
na confluência de tristezas e saudades que engendram, em conjunto, a música do povo do Brasil.

[...]

És samba e jongo, chiba e fado, cujos

Acordes são desejos e orfandades

De selvagens, cativos e marujos:

E em nostalgias e paixões consistes,

Lasciva dor, beijo de três saudades,

Flor amorosa de três raças tristes. (BILAC, I9I9, p. I9).

A bela imagem do último verso define a música brasileira como "flor amorosa", brotada de paixões dolorosas, de um lirismo erótico e sofrido. Essa chave de ouro de um soneto finamente parnasiano retoma, muito provavelmente, o "Flor amorosa" que intitulou, ainda no século XIX, uma polca de Joaquim Callado3.

Inspirado e inspirador, o texto de Bilac representa bem certa tradição do lirismo literário de ascendência lusitana, mas pouco diz da poética (então e ainda agora) muito mal conhecida, por nós, dos povos indígenas e afrodescendentes. Somente no século XX começamos realmente a travar contato com ela. Isso aconteceu graças às modernas pesquisas da etnografia e da literatura oral, mas sobretudo graças à música popular mediatizada, primeiro espaço a se abrir no Brasil para o som, a voz e a palavra dos negros e dos pobres sem escolaridade.

No mesmo ano de I9I7, surgia o que ficou sendo considerado como o primeiro registro fonográfico de um "samba" (apesar de ser na verdade um maxixe, e de se terem já apontado gravações anteriores que ostentavam a mesma denominação), gênero musical que viria a ser o principal ícone de nossa cultura popular : o "Pelo telefone”, de Donga e Mauro de Almeida, lançado pela Casa Edison na voz de Bahiano. Uma letra formada de estrofes meio desconexas, mas associadas pela verve crítica e bem-humorada, pelas menções à vida boêmia, pela linguagem coloquial, enfim, pelo referencial da vida urbana e moderna. Nada a ver com o lirismo melancólico que caracterizava a música popular brasileira nos versos de Bilac. Uma possível aproximação com a cultura literária, efetivamente, nos levaria muito mais para o lado da estética e visão de mundo modernistas, então em gestação, contrapostas à imagística suspirosa que ainda dominava a produção apegada à tradição parnasiana ou simbolista.

3 A polca "Flor amorosa", de Joaquim Antonio da Silva Callado, veio a ser considerada um marco inaugural do choro. Era entre nós a primeira composição de música popular urbana que fugia dos ritmos importados da Europa e apresentava um caráter mais "brasileiro”. A música foi publicada pela primeira vez em I880 e gravada em I902 pela Casa Edison. A letra foi adicionada posteriormente por Catulo da Paixão Cearense, e a primeira gravação de letra e música data de I929. No registro de I902, puramente instrumental, com destaque da flauta, "Flor amorosa” é uma peça de andamento rápido, animada, brejeira e dançante. Gravações posteriores fizeram dela um verdadeiro choro, com andamento bem mais lento, sublinhando os floreios do contorno melódico. 
Nos anos seguintes, a música popular tomaria configurações diversas, expandindo e multiplicando seus formatos e expressões, ocupando cada vez mais o espaço sonoro do disco e do rádio. No final da década de I920, a popularização do carnaval e a expansão do samba ajudam a configurar, na cultura musical da cidade, uma nova imagem de Brasil, caracterizada pelo humor, pela brincadeira, pela malandragem. Até o final dos anos I940, o samba impera no rádio e no disco, promovido, com o apoio do Estado populista, a música símbolo da nação. Celebrado como império da alegria e do prazer, é associado a festa, dança, batucada, ritmo. Nesse período, a tópica da tristeza, quando ocorre, é geralmente mitigada pela forma musical animada e dançante, pela ênfase rítmica, pelo humor, pela verve malandra - características compartilhadas com as marchinhas carnavalescas. Ainda não há um repertório consistente do subgênero samba-canção, que se dedicaria a cantar, em tom dolente e ritmo ameno, os pesares da alma.

\section{SAMBa DE MALANDROS X SAMBa-CANÇão}

Apontado como inaugurador do samba-canção, em I928, "Ai, Ioiô" (Luiz Peixoto e Henrique Vogeler) é na verdade uma... canção. Pertence à linhagem das serestas (como "Chão de estrelas", de Orestes Barbosa e Silvio Caldas, I937) e valsas (como "Deusa da minha rua", de Newton Teixeira e Jorge Faraj, I939), que, na esteira das modinhas, combinam versos de expressão emotiva e sentimental com melodias cantábiles, em andamento lento. Os compositores e o estilo lírico dessas canções ligam-se geralmente à classe média e à sua educação musical e/ou literária.

O samba-canção realmente samba, de extração popular e tributário de uma cultura oral, já existe nos anos I930, mas de modo escasso e tímido. Alguns sambas melancólicos de Noel Rosa, como "Pra que mentir" (melodia de Vadico), já estão assentando as bases do subgênero. Na obra do Poeta da Vila, há quatro composições designadas "samba-canção" e três "canções". Porém várias outras peças, como "Feitio de oração"4, apesar de inicialmente executadas com levada rítmica e andamento de samba-samba ${ }^{5}$, ganhariam décadas depois versões mais lentas e dolentes, como belos e legítimos exemplares de samba-canção.

A imprecisão inicial da denominação "samba-canção" e a dificuldade de

4 São inúmeros os registros de "Feitio de oração". Basta comparar o primeiro deles, por Francisco Alves e Castro Barbosa, e I933, com a grande maioria dos registros posteriores, como os de Nelson Gonçalves, João Nogueira, Gal Costa, Marisa Lima etc.

5 Já nos anos I920 e I930, o estilo rítmico e poético inicial do samba, configurado notadamente pelos compositores do Estácio (Ismael Silva e Bide entre eles), vai incorporando diferentes nuances e variações que resultarão numa multiplicidade de subgêneros, designados por expressões compostas (samba-canção, samba-enredo, samba-exaltação, samba-de-breque, samba-choro etc.) e reunidos na grande e longeva linhagem do samba. O termo que emprego aqui, "samba-samba", é um neologismo que não faz parte da nomenclatura crítica assentada. Com ele, refiro-me, por um lado, a um tipo de samba associado aos primeiros tempos do gênero, antes que os seus caminhos se multiplicassem em numerosas vertentes; por outro lado, e em contraposição ao samba-canção, enfatizo a pregnância rítmica e dançante desse formato seminal. 
circunscrever e conceituar o subgênero em formação vêm, em boa parte, da identificação frequentemente estabelecida entre samba-canção e samba-de-meiode-ano. Ora, o samba-de-meio-de-ano, tal como o samba-de-quadra, não chega a constituir uma forma com características próprias. Ambos, designados por sua situação no tempo e no espaço, definem-se basicamente pelo que não são: não visam o carnaval nem o desfile das escolas de samba. Pensá-los como categorias musicais em si incorre no equívoco, aliás frequente, de pensar a história, a estética e a cultura do samba tendo sempre como principal referência o carnaval.

A fim de entender o samba-canção como uma linguagem de características próprias, podemos pensá-lo a partir de sua oposição ao que chamo de samba "malandro" (cf. MATOS, I982): aquele que, desde os anos I920, promove a ideologia e a linguagem malandras, associadas, no plano melódico, à perícia rítmica e à levada sincopada que produzem a "ginga" característica.

Essa dicção poético-musical foi elaborada inicialmente pelos sambistas do Estácio, reunidos no bloco Deixa Falar. Entre eles, o primeiro compositor a se distinguir foi Ismael Silva, quando Francisco Alves comprou parceria e lançou o samba de Ismael "Me faz carinhos" (I927).

Mulher, tu não me faz carinhos

Teu prazer é de me ver aborrecido

Ora, vai mulher, estás contrariada

Tu não és obrigada a viver comigo

$[. . .]^{6}$.

Queixa, crítica e sarcasmo se unem na culpabilização da mulher e na rejeição ao envolvimento afetivo. Essa temática já era frequente na obra de Sinhô, o qual, antes mesmo dos malandros do Estácio, foi o primeiro compositor a patentear a malandragem com traço distintivo do samba e do sambista. E a malandragem era o oposto do lirismo sentimental; ostentava um ceticismo blasé e jocoso, como o que está nesse mesmo samba de Ismael:

[...]

A maré que enche vaza

Deixa a praia descoberta

Vai-se um amor e vem outro

Nunca vi coisa tão certa

$[\ldots]$

Quando, no ano seguinte, Alcebíades Barcelos, o Bide, lança “A malandragem” na

6 As citações de letras de samba foram feitas a partir de muitos fonogramas dispersos, disponíveis em muitos sítios da internet e em coleções particulares de música digitalizada. Nesses casos, contento-me em citar os compositores, a data de lançamento da obra e, eventualmente, o intérprete. 
voz do mesmo Francisco Alves7, a conversa já é um pouco diferente. O samba começa falando de abandonar a malandragem e a orgia para dedicar-se à bem-amada:

\author{
A malandragem \\ Eu vou deixar \\ Eu não quero outra vez a orgia \\ Mulher do meu bem-querer \\ Esta vida não tem mais valia \\ [...].
}

Nas estrofes seguintes, porém, a conversa muda de tom, deixando perceber que a opção pelo compromisso amoroso representa, na verdade, uma nova modalidade de malandragem:
$[\ldots]$
Arranjei uma mulher
Que me dá toda vantagem
Vou virar almofadinha
Vou deixar a malandragem
Esses otários que só sabem
É dar palpite
Quando chega o carnaval
A mulher lhe dá o suíte
Você diz que é malandro
Malandro você não é
Malandro é Seu Abóbora
Que manobra com as mulhé.

Com suas versões e sentidos mutáveis, escorregadios e até disparatados, as representações da ética e da estética malandras convergem todavia na contraposição ao romantismo amoroso. Explorar a prostituição, como na letra supracitada, é procedimento assumido, até com orgulho, pelo personagem malandro nesse final dos anos I920. Quando se fala em "amor de malandro", ele traz um componente autoritário, cínico e violento:
O amor é o do malandro
Oh! Meu bem
Melhor do que ele ninguém
Se ele te bate
É porque gosta de ti
Pois bater-se em quem

7 Segundo uma prática muito usual no meio, Francisco Alves, ao gravar o samba, adquiriu também a composição, inscrevendo na etiqueta do disco seu nome como autor, ao lado do nome de Alcebíades Barcelos. 
Não se gosta

Eu nunca vi

[...].

(“Amor de malandro”, de Ismael Silva, Freire Júnior e Francisco Alves, I929).

A figura malandra ganha outras feições, talvez mais amenas, nas décadas seguintes; mas nunca se abandona ao sentimento nem ao padecimento amoroso. Isso vale também para as suas versões femininas, as quais frequentam, em contrapartida, o samba lírico-amoroso - ali onde é o sujeito masculino que verte lágrimas, abandonado pela mulher ingrata, falsa e fria.

A contraposição entre os dois veios poético-musicais do samba é expressa por Noel Rosa em “Rapaz folgado" (I933), onde ele questiona a apologia à figura malandra feita por Wilson Batista em “Lenço no pescoço" (I933), e conclui:

Da polícia quero que escapes

Fazendo samba-canção

Eu já lhe dei papel e lápis

Arranje um amor e um violão.

A proposta de Noel se expressa, no início da letra, em termos estéticos, aconselhando que o rapaz abandone o modo de se vestir tipicamente malandro; e conclui advogando uma troca de nomes:

\author{
Proponho \\ ao povo civilizado \\ não te chamar de malandro \\ e sim de rapaz folgado.
}

Uma escuta atenta percebe que a estratégia artificiosa aconselhada por Noel é, ela mesma, o produto de um espírito malandro. Mas o que nos interessa aqui é que, elegendo o "samba-canção" como alternativa para a criação poético-musical do sambista, ele aponta a distinção característica entre os dois grandes conjuntos temáticos e estilísticos do gênero. E este é sem dúvida um caminho para chegar a uma noção mais consistente sobre a variante do samba que então começa a se configurar.

O samba-canção mantém o esquema rítmico básico e o contexto social do samba, mas tem andamento mais lento, que ajuda a realçar o desenho mais elaborado da melodia. Investimento melódico e atenuação da pulsão rítmica produzem uma música que convida menos à dança, e mais à escuta e ao canto ${ }^{8}$.

$\mathrm{Na}$ linguagem representativa do plano verbal, embora compartilhe o contexto social e cultural do samba-samba, o samba-canção desvia o foco discursivo das cenas exteriores, da crônica social, dos fatos e diálogos cotidianos e frequentemente públicos; e volta-se, com sua letra séria, melancólica ou dramática, para o interior do

8 O samba-canção mais dançante é o que se aproxima do bolero, nos anos I950. Mas é dança de salão, de gafieira, e se dança em pares enlaçados, ao contrário do samba-samba, que se dança solto, em roda ou cortejo. 
sujeito individual, em monólogos ou diálogos íntimos cujo teor é mais frequentemente amoroso, mas também pode ser reflexivo, moral, existencial.

Apenas a partir da segunda metade dos anos I940 o samba-canção assim bem caracterizado, praticado por compositores de extração social humilde e baixo letramento, ganha espaço e firma-se como subgênero da grande família sambista. Um autor característico de samba-canção nesse período é Lupicínio Rodrigues. Começa a gravar na segunda metade dos anos I930, e alcança sucesso com "Se acaso você chegasse” (Lupicínio Rodrigues e Felisberto Martins, I937); mas permanece em segundo plano por um bom tempo, só começando realmente a se destacar a partir de "Nervos de aço", em I946 (por Francisco Alves) - este sim, um bom exemplo de samba-canção. Seu maior sucesso será "Vingança” (I95I, por Linda Batista). A ele se atribui a difusão da expressão "dor de cotovelo".

Da mesma geração de Lupicínio (I9I4-I974), Cartola (I908-I980) e Nelson Cavaquinho (I9II-I986), também considerados hoje importantes autores de samba-canção, são naquele período reconhecidos no meio do samba, mas gravam relativamente pouco. Somente se tornarão familiares ao grande público nos anos I960, já depois da fase da música de "fossa" e do samba-canção abolerado dos anos I950.

\title{
RIR PARA NÃo CHORAR 9
}

Esta breve digressão sobre a feição mais tristonha e sentimental do samba não pretende aprofundar a distinção entre o bom humor do samba sincopado e festeiro e o lamento do samba-canção. Ao contrário, interessa-me a maneira como, na música popular das primeiras décadas, e particularmente no quadro do que se chamava de "samba", os opostos também podem combinar-se, de modo muitas vezes ambíguo. E por aí voltamos à questão de Berenice Corti sobre o caráter paradoxal da alegria do samba.

Na poética do samba da chamada “época de ouro", inclusive no que se produz para o repertório carnavalesco, nem tudo é alegria e malandragem. No meio do riso e da festa, conforme observou Corti (20I7), há frequentemente notas de queixa e de dor. E, para além do carnaval, a combinação de pena e prazer ocorre em diversos âmbitos e repertórios, constituindo um verdadeiro leitmotiv da autoimagem do samba, como a que se apresenta em “Alegria”, de Assis Valente e Durval Maia, I937:

\author{
Minha gente \\ Era triste e amargurada \\ Inventou a batucada \\ Pra deixar de padecer \\ Salve o prazer, salve o prazer \\ [...].
}

9 "Rir para não chorar” é o título, em I932, de uma marcha-rancho do bloco Deixa Falar, composta por Alcebíades Barcelos. Não encontrei o registro fonográfico (creio que não existe), mas, segundo Jota Efegê (I978), era uma melodia pomposa, bonita e cadenciada. O coro cantava: "Rir para não chorar/ Quando passar/ O Deixa Falar./ Vejam a nossa beleza/ Quanta riqueza/ Para quem pode enfrentar/ Enfrentar!”. 
Ou no lindo "Cantar para não chorar", de Paulo da Portela e Heitor dos Prazeres, lançado no ano seguinte:

\author{
Rir para iludir \\ Cantar para não chorar \\ Beber para esquecer \\ O nome daquela ingrata \\ Que me fez sofrer \\ [...].
}

Várias décadas depois, Caetano Veloso apontaria a longevidade dessa figura ambígua, estampada na face e na força do samba:

A tristeza é senhora

Desde que o samba é samba é assim

A lágrima clara sobre a pele escura

$[\ldots$.

Cantando eu mando a tristeza embora

$[\ldots]$

O samba é pai do prazer

O samba é o filho da dor

O grande poder transformador

[...].

(“Desde que o samba é samba", Caetano Veloso, I993).

Através das artes do samba, o que deriva da dor resulta em prazer; o sujeito sai do abatimento, toma ânimo, move o corpo e solta a voz. Nesse "poder transformador", nesse trânsito de mão dupla entre estados mutáveis da alma e do corpo reside um dos grandes mistérios e encantos do samba. E o nexo entre sentimentos e sensações díspares dessa poética verbo-voco-musical assume formas e sentidos que não se podem sintetizar ou explicar meramente pelas origens étnicas e históricas do gênero; nem pela adjacência entre infortúnio cotidiano e festa carnavalesca; nem por analogia com o dissídio da verve modernista face ao lirismo nostálgico dos poetas novecentistas.

Para experimentar e pensar tais formas e sentidos em sua especificidade e inteireza, é preciso escutar o próprio samba, atentar não só para o que ele diz mas também para de que maneira o diz: considerá-lo em sua linguagem integral, gerada na conjunção de letra, música e voz.

Nas décadas de I930 e I940, o encontro entre alegria e dor é tópico muito frequente na letrística do samba. Manifesta-se geralmente de modo bem padronizado, quase formular, manejando verdadeiros estereótipos recorrentes, numa poética que cultiva a emulação e a palavra compartilhada. Termos-chave como "sofrer"/"chorar" e "rir"/"sorrir" aparecem constantemente vinculados, projetando uma espécie de sistema simbólico e moral. Via de regra, o pranto se dá por motor da canção, mas a 
ele o canto sobrepõe sua voz, como estratégia de compensação e/ou dissimulação. Correlatamente, o samba (a orgia) é o que faz esquecer, oculta e, ao mesmo tempo, exalta os padecimentos do sambista:

\author{
Ando na orgia para esquecer \\ Canto para não mostrar o meu padecer \\ Meu primeiro amor me abandonou \\ [...] \\ Meu viver é triste, quem me vê não diz \\ Vivo a cantar e não sou feliz. \\ (“Ando na orgia”, Bide e Marçal, I938).
}

\title{
BIDE E MARÇAL
}

Foi quando escutei com atenção a obra da dupla Bide e Marçal que essa face ambivalente do samba pela primeira vez se expôs nitidamente aos meus ouvidos. Naquele tempo, eu fazia pós-graduação em Literatura e estava concluindo, meio por fora dos trilhos acadêmicos da época, minha dissertação de mestrado ${ }^{\mathrm{T}}$. $\mathrm{O}$ tema era a poética da malandragem no samba; o corpus reunia principalmente sambas de Geraldo Pereira e Wilson Batista; e a análise destacava a crônica social, o humor, a linguagem cifrada, a astúcia elegante da figura malandra. O estudo foi publicado em I982, sob o título Acertei no milhar: samba e malandragem no tempo de Getúlio (MATOS, I982) ${ }^{\text {Ir }}$.

$\mathrm{Na}$ dissertação, a fim de mapear a diversificação do samba desde os anos I930, eu tentava discriminar três modalidades poético-musicais do gênero: ao lado do "samba malandro" que centralizava minha atenção, o "samba lírico-amoroso" (em parte identificado ao samba-canção) e o "samba apologético-nacionalista" (em parte identificado ao samba-exaltação e ao samba-enredo). Era uma classificação bem esquemática e meio ingênua; porém, na exploração incipiente dos mistérios do samba, valeu a pena recorrer a ela para me orientar na profusão e na diversidade daquele enorme acervo - o samba - que me seduzia, mas era todo temperado de estranhezas para meu gosto e meu conhecimento de base erudita e livresca.

Não precisei ir longe para perceber a fragilidade da classificação. Em I978, mesmo ano da conclusão de minha dissertação, Nilton "Mestre" Marçal lançou seu primeiro disco, interpretando sambas da parceria de Armando Marçal, seu pai, com Alcebíades Barcelos, o famoso Bide. A primeira coisa que me tocou, ao ver o álbum Marçal interpreta Bide e Marçal, foram as imagens do invólucro. Na capa frontal, há fotos dos muitos artistas famosos que compõem o coro das faixas, com Mestre

Io A dissertação, orientada por Silviano Santiago na PUC-RJ, intitulou-se O malandro no samba: uma linguagem na fronteira (MATOS, I98I).

II A tópica da malandragem na música popular carioca, porém, vinha de bem antes. Tinha sido, por exemplo, trabalhada por Sinhô desde o início dos anos I920. E se tornara uma espécie de "patente" dos sambistas que se distinguiram desde o final dessa década, notadamente no quadro das escolas de samba e no grupo do Estácio que atuava na Deixa Falar. 
Marçal no meio deles. No centro da contracapa, uma foto onde Francisco Alves, elegantemente vestido, violão em punho, olhando para a câmera, estampa seu sorriso de cantor-cartaz, ladeado pelos dois compositores, mais simplesmente vestidos, cada qual com seu tamborim. Bide também olha para a câmera, meio de lado; Marçal está de perfil, atento ao "Rei da Voz". Mas o que me chamou mesmo a atenção foram as duas grandes fotos em close dos parceiros, nas duas bordas da contracapa, ladeando a foto central. Semiperfiladas, voltadas para fora, em direções opostas, elas contrastam entre si: um Bide satisfeito, garboso com sua gravata e seu chapéu, discretamente sorridente; e um Marçal de camiseta, sombrio, tímido, tristonho.
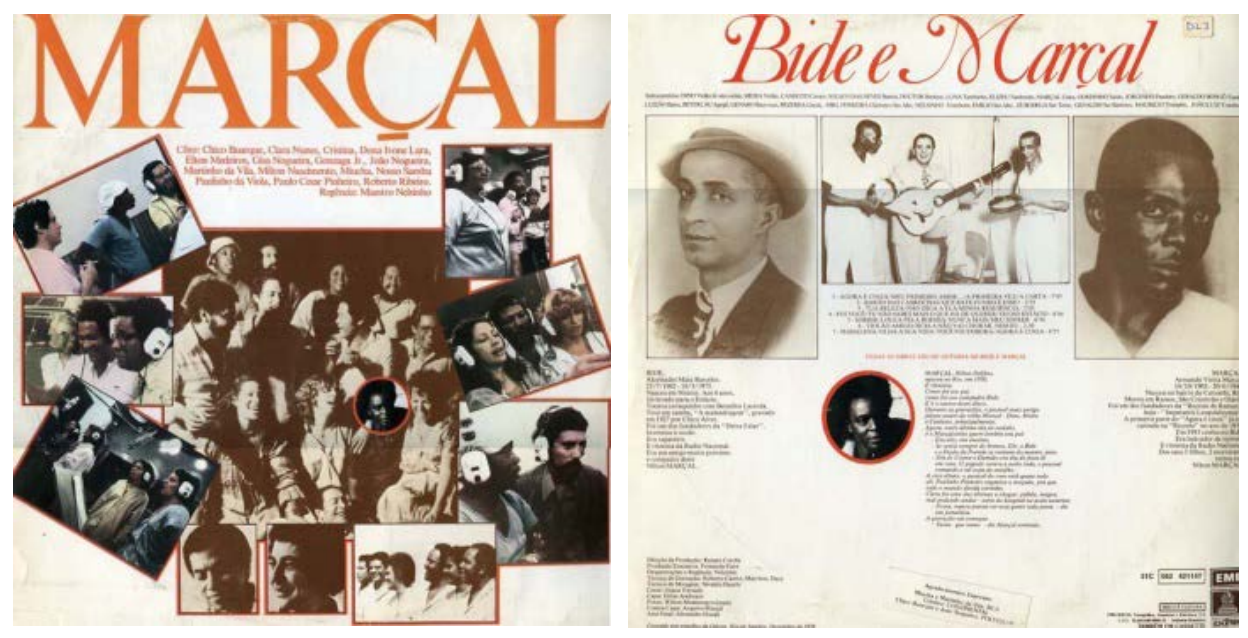

Figurar - Capa e contracapa do LP de Mestre Marçal, Marçal interpreta Bide e Marçal. EMI-Odeon, I978

Quando ouvi os sambas do disco, senti ali um contraste semelhante: alegria e tristeza, desenvoltura e queixa. Fiquei tão fascinada que projetei um trabalho sobre a dupla e inscrevi o projeto num concurso da Fundação Nacional de Artes - Funarte. Não ganhei o concurso, e a ideia foi abandonada; mas a curiosidade ficou. Várias décadas mais tarde, quando a postagem de Berenice Corti (20I7) voltou a levantar a questão das alegrias paradoxais do samba, voltou-me também a vontade de trabalhar com ela. Lembrei-me daquela primeira impressão, e fui perseguir a pista que os sambas de Bide e Marçal pareciam oferecer.

A parceria entre Bide e Marçal foi uma das mais constantes e produtivas da música popular brasileira. Era uma dupla tão ajustada e fiel que os parceiros chegavam a ser imaginados como uma só pessoa. Conta-se que, quando a TV Record de São Paulo organizou uma Bienal do Samba em I968,

[...] a produção do evento decidiu convidar compositores importantes no gênero, para apresentarem suas obras e serem homenageados, independente da competição. Entre os convites expedidos individualmente, estava lá um para o "Senhor Bide Marçal", os produtores pensando que a dupla fosse uma só pessoa. (ACADEMIA DO SAMBA, s/d). 
Alcebíades Maia Barcelos nasceu em Niterói (RJ), em I902. Ainda menino, foi com a família morar no Rio de Janeiro, no bairro Estácio de Sá - ali mesmo onde, 20 anos depois, com seu irmão Rubem Barcelos e com Ismael Silva, Buci Moreira, Nilton Bastos, Brancura e outros bambas, ajudaria a criar o bloco Deixa Falar, considerado como a primeira "escola de samba". Cedo se destacou como ritmista, atuando pioneiramente na instrumentação das baterias do cortejo carnavalesco. A ele se atribui a introdução do surdo e do tamborim no conjunto percussivo da escola de samba.

O primeiro êxito de Bide é "A malandragem", gravado por Francisco Alves na Victor em I928. Mas é o encontro com Marçal, em I933, que lhe abre o caminho do sucesso junto a um público mais amplo. A produção de Bide é intensa até a morte do parceiro, em I947. A partir daí, vai deixando de compor e dedica-se às atividades de ritmista. Em I973, deixa o bairro do Estácio pelo Conjunto Residencial dos Músicos, em Inhaúma, onde morre dois anos depois, aos 73 anos, praticamente cego e paralítico.

Armando Marçal nasceu no Rio de Janeiro em I902 e faleceu em I947, acometido de infarto no escritório da RCA-Victor. Sua biografia é mais curta e menos conhecida do que a de Bide, mas seu nome será levado adiante no mundo do samba não só pela obra que deixou, quase toda com o parceiro principal, como também pelos seus descendentes, o filho Nilton Marçal e o neto Marçalzinho, ambos profissionais reconhecidos, principalmente como ritmistas.

De família pobre, teve uma infância difícil e cursou com dificuldade a escola primária. Tornou-se lustrador de móveis e nunca deixou de exercer a profissão para ganhar a vida - ao contrário de Bide, que abandonou o ofício de sapateiro para viver do samba. Mas já se destacava como compositor e ritmista na Escola de Samba Recreio de Ramos, fundada em I93I. Marçal chegou a ser vice-presidente da escola, e na sua quadra lançou vários sambas de sua lavra, entre os quais “Tu partiste”:

Tu partiste

Com saudades eu fiquei

O nosso amor foi uma chama

Que o sopro do passado desfez

Agora é cinza

Tudo acabou e nada mais.

Cantado no carnaval de I933, o samba depois se transformou com a contribuição de Alcebíades Barcelos, inaugurando a parceria de longo alcance: ganhou segunda parte, um fraseado mais ágil e elegante e o título "Agora é cinza".

Você partiu

Saudades me deixou

Eu chorei

O nosso amor foi uma chama

O sopro do passado desfaz

Agora é cinza

Tudo acabado e nada mais 


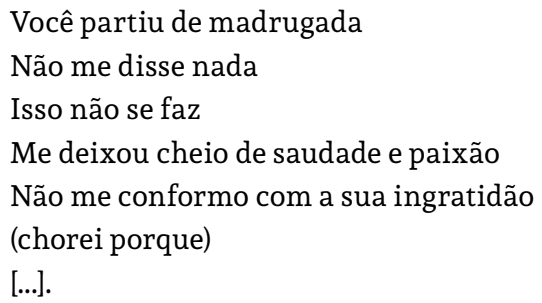

Os compositores procuraram Mário Reis para dizer-lhe que tinham um samba para ele e outro para Francisco Alves. Mário solicitou-lhes que os mostrassem antes a Chico Alves, com quem estava estremecido. Entre "Agora é cinza" e "Durmo sonhando", Alves preferiu o segundo. Mário Reis gravou "Agora é cinza” na Victor em outubro de I933, e o samba venceu o concurso de músicas carnavalescas de $1934^{\mathrm{I} 2}$. Seria o primeiro e maior sucesso da dupla, regravado mais de cem vezes. Em I975, foi eleito o melhor samba de todos os tempos por um júri reunido pelo produtor Marcus Pereira.

Ainda em I934, multiplicaram-se as gravações de obras da parceria Bide e Marçal por nomes prestigiosos como, além dos já citados Francisco Alves e Mário Reis, Almirante, Carmem Miranda e outros. Começava a história de uma colaboração intensa e constante ${ }^{\mathrm{I}}$, que produziria pelo menos 53 sambas, duas valsas e duas marchas. Nilton Marçal (2000) fala num acervo de I20 títulos produzidos pela dupla. Confesso que só consegui identificar 57. No lançamento desse repertório, os intérpretes mais frequentes foram Carlos Galhardo (I4 fonogramas) e Gilberto Alves (9).

\section{LETRAS TRISTES EM MÚSICAS ALEGRES E OUTROS NEXOS ENTRE DIFERENÇAS}

Alguns dizem que Marçal era mais responsável pelas letras, e Bide, pelas melodias. No encarte do álbum Bide, Marçal e o Estácio, essa repartição de tarefas é inclusive associada à mudança de estilo observada na obra de Bide a partir da parceria com Marçal e ao contraste entre letra e melodia que se verifica em boa parte das composições da dupla:

A parceria posterior e mais constante [de Bide], com o letrista Marçal, desprezou o rico filão crítico-musical da MPB e se restringiu praticamente à temática lírico-amorosa. $\mathrm{O}$ exercício do prazer de fazer sambas contrastado pelo sentimento do desprazer de seus enredos. (MORAES, I979, p. I).

Mas também se diz que compunham da forma tradicional, um fazendo a primeira parte e o outro, a segunda. Em outro texto (sem assinatura) no encarte supracitado, a respeito do feitio mais definido e funcional que as segundas partes dos

I2 No mesmo ano, a Recreio de Ramos foi vitoriosa no desfile das escolas.

I3 Na verdade, "Agora é cinza" não é a primeira composição da parceria. "Companheiro dileto", assinado por ambos, já aparece num jornal de modinhas em I93I (cf. MORAES, I979, p. 6), mas só seria gravado em I936, por Silvio Caldas. 
sambas adquiriram a partir de sua mediatização fonográfica, comenta-se: "Segundo Juarez Barroso, a Bide deve-se creditar o mérito de ter sido 'o grande valorizador das segundas, dando-lhes a mesma elaboração poética e melódica da primeira parte, tirando-lhe aquele caráter suplementar" (MORAES, I979, p. 6).

Severiano e Mello (I997, p. I29) afirmam: "Depois de prontas, as partes se ajustavam com facilidade, graças a uma perfeita identidade de estilos".

Parece-me mais plausível a hipótese das funções compartilhadas. Imaginar um alegre Bide com sua música animada e um melancólico Marçal com sua poesia lamuriosa seria uma ideia esquematicamente confortável, que corresponderia à minha sensação inicial ao ver as fotos dos dois na contracapa do álbum de Nilton Marçal. Mas não seria coerente com a prática costumeira de composição naquele período e naquele meio. Nem com as muitas fotos de um Marçal sorridente e os depoimentos (como os de seu filho Nilton Marçal) que recordam um sujeito alegre e festeiro (MARÇAL, 2000).

O que importa aqui, de toda maneira, não é a vida e o caráter de cada parceiro, mas o modo como seus talentos se combinaram e convergiram no caráter e na vida de suas obras, nas quais tudo se integra e se harmoniza, inclusive a dor e o prazer. Entre os dispositivos que articulam o pesar e o gozo, o que primeiro salta aos ouvidos é, como apontou Corti (20I7), a conjunção ambivalente de letra triste e música alegre.

Versos sofridos e melodia animada, sustentada por um ritmo ágil e dançante imposto pelo acompanhamento de percussão e sopros. Esse padrão não é exclusivo da parceria Bide e Marçal. Está bastante presente na poética dos sambas dos anos I930 e I940, e também se encontra na própria obra de cada um deles com parceiros diferentes. Teve larga sobrevida na tradição do samba, e ainda persiste no trabalho de compositores mais tradicionais. A respeito de "Coração em desalinho", de Ratinho e Diniz, gravado por Zeca Pagodinho em I986, Túlio Villaça faz comentários que se poderiam facilmente adequar a vários sambas do repertório que estudamos.

Trata-se de uma espécie de celebração da própria tristeza. Para um observador externo, não pode deixar de soar estranho e até ridículo a ideia de um coro cantando entusiasmado:

\author{
Agora \\ Uma enorme paixão me devora \\ Alegria partiu, foi embora \\ Não sei viver sem teu amor \\ Sozinho curto a minha dor!
}

\begin{abstract}
“Coração em desalinho" é uma grande contradição entre letra e melodia. Se na primeira parte, esta segue quase reta, como em contrição, aos poucos a amplitude vai aumentando calculadamente, com a empolgação crescendo continuamente até escalar o agudo na última estrofe, quando ocorre o correspondente a um rompante de desespero, só que com o sinal invertido, tornado numa explosão de alegria!. (VILLAÇA, 2OII).
\end{abstract}

Nos sambas de Bide e Marçal, como nos de vários contemporâneos seus, a tristeza da letra é quase sempre creditada às decepções amorosas, à mulher ingrata, à situação de abandono, à quebra das ilusões, à perda do primeiro amor. O infortúnio 
é enfatizado pelo contraste com a lembrança dos momentos felizes que o precederam. A ventura alcançada no amor é sempre uma lembrança que pertence ao passado. Mesmo num caso excepcional em que tal ventura se dá no presente, ela é toldada pela certeza de que o futuro trará inevitavelmente saudade e sofrimento:

No encontrar de dois olhares nasceu nosso amor

Vivo contente em te amar meu bem

Mas eu fico triste ao me lembrar

Que a morte vai nos separar

Hoje tenho a felicidade

E mais tarde sei que vou chorar

[...].

(“Vivo deste amor”, Bide e Marçal, I934).

Às vezes, como já vimos, o contraponto ou a resposta existencial do sujeito aos dramas emocionais é buscar a boemia, cantar, sorrir, aparentar alegria. A reação ao sofrimento pode se dar também na clave do rancor e do desejo de vingança, enfatizando a culpabilização da mulher:

Quanto eu sinto

A tua ingratidão

Sofro com resignação

E tu jamais terás o meu perdão

Os prantos meus não mais verás

De mim jamais hás de sorrir

Hei de te ver a padecer

A dor que me fizeste sofrer

(Por isso é que eu digo)

[...].

(“Quanto eu sinto", Bide e Marçal, I935).

Geralmente, porém, o teor da letra tende a absorver-se inteiramente na queixa e no abatimento, sem nem sequer evocar a obliteração ou alívio oferecidos pelo canto e pela orgia.

Meu primeiro amor

Vem ouvir meus ais

São lamentos d'alma

Que em agonia se desfaz

Minh'alma não suporta tanta dor

Tenha pena de mim ó meu primeiro amor

Sofro só por te querer

Não tens pena de mim

Amar sem ser amado 


\section{É bem triste viver assim}

[...].

(“Meu primeiro amor”, Bide e Marçal, I938).

Nesses casos, não é dentro do campo verbal que se trava o jogo de emoções e atitudes contrapostas ou paradoxais. A ambivalência não é uma figura meramente intelectual, ela ressoa no plano complexo e sensível da canção. Podemos vivenciá-la ao escutar o corpo completo e polifacetado da obra, que inclui melodia, performance vocal e acompanhamento instrumental. É o conjunto desses fatores que encena um quadro de pulsões contrastivas, gerando a "alegria paradoxal do samba".

A expressão linguística com sua tenaz melancolia vai atrelar-se e acomodar-se a um percurso musical alegre e festivo que funciona como verdadeiro motor da canção: o ânimo melódico e a propulsão rítmica e percussiva sacodem o corpo e incitam à dança. Em vários sambas (como os já citados "Quanto eu sinto" e "Agora é cinza"), a incidência de breques, com ou sem adição de texto, adiciona brejeirice e descontração que também modalizam a seriedade da letra.

Note-se que a dimensão melódica dos sambas de Bide e Marçal é o elemento mais destacado pela crítica, responsável pela inventividade que produz "sambas fluídicos, cálidos, envolventes” (MORAES, I979, p. I). As letras são relegadas a segundo plano, como se não apresentassem muito mais do que banalidade, sucessão de clichês e fórmulas repetidas de um samba para outro. A rejeição aos motivos compartilhados entre obras e autores pode atribuir-se, em parte, a uma ideologia da cultura letrada que prioriza a estética "artística" da originalidade em detrimento da estética "popular" da repetitividade (cf. ULHÔA, I995). Mas estas mesmas repetição e previsibilidade ajudam a compor, no quadro amplo da poética musical da dupla, uma figura de traços marcantes e singulares. Essa figura representa uma espécie de sistema simbólico, moral, cultural, formado por variadas camadas de sentido e expressão - entre elas, os estratos de teor social e histórico, bem como os que decorrem do contato da cultura oral com linguagens poéticas de matriz literária ${ }^{\mathrm{I}}$.

A interação entre os planos discursivos (letra, melodia, esquema rítmico, interpretação vocal, instrumentação e arranjo) não é estável e definida em suas funções semânticas e estéticas. Na própria melodia se insinuam, pairando sobre o apelo e a pregnância rítmica, gestos que apontam para um estado mais lírico: o investimento nas curvas e no desenho amplo e cuidadoso das alturas aproxima o estilo daquele que seria mais tarde desenvolvido no samba-canção, em andamento moderado ou lento. Isso porém não refreia a animação e o apelo rítmico - como em "Durmo sonhando", no qual uma letra tristíssima alia-se a uma música tão animada quanto uma marchinha de carnaval.

Durmo sonhando

Desperto chorando

Lembrando o tempo feliz que passou

I4 Alguns autores apontam na estética do samba-canção procedimentos de contrafação em relação à poesia literária. Ver, por exemplo: Borges, 1982. 


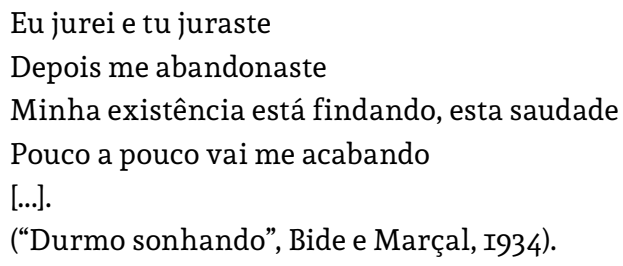

Essa mesma animação, por outro lado, pode ser atenuada ou contrastada pela performance vocal. A elocução do intérprete pode imprimir a uma melodia saltitante de andamento acelerado uma tonalidade doce, uma suave melancolia. Em "Durmo sonhando", o senso do fluxo melódico, a voz perfeitamente colocada e o legato competente de Francisco Alves aparam as arestas da segmentação sonora e contradizem o convite à dança, solicitando ouvidos que escutem, atentos e comovidos, a sua queixa.

A interpretação vocal pode infletir o sentido ou o efeito da canção para a exaltação ou para o abatimento. A esse respeito, é interessante lembrar que os dois maiores cantores da época tinham estilos bastante diversos, o que não os impediu de formar, também no começo dos anos I930, uma dupla inesquecível. Nela, as vozes e dicções praticamente opostas de Francisco Alves - com sua voz potente e empostada a serviço do lirismo e do drama - e Mário Reis - com sua voz discreta e jocosa, explorando meio ironicamente as inflexões da voz falada - faziam um par perfeito.

E é preciso observar também os instrumentos e o arranjo musical. Tanto Bide quanto Marçal foram excelentes ritmistas, considerados a melhor dupla de tamborins de sua época nos estúdios de rádio e gravação. Presença marcante nas gravações originais, a percussão será também enfatizada na leitura que Nilton Marçal faz da obra da dupla, no LP de I978. Além de cantor, foi ele próprio exímio percussionista, comandando por mais de vinte anos a bateria da Portela. Caminho semelhante foi seguido por Marçalzinho, que atuou em várias escolas como diretor de bateria.

Algumas das composições de Bide e Marçal celebram os instrumentos que contribuíram para o êxito e renome dos autores no meio do samba. "Barão das cabrochas" exalta o tocador de surdo, cuja invenção é costumeiramente atribuída a Bide:

\author{
Controlo a escola \\ No surdo eu dou bola \\ Lá em cima o rei pequeno sou eu \\ Barão da cabrochas, luminoso cartaz \\ Se eu não estiver na escola \\ Nada se faz \\ [...]. \\ (“Barão das cabrochas”, Bide e Marçal, I945).
}

E o apego ao tamborim é o tema de um dos raros sambas que Marçal compôs sem a colaboração de seu parceiro fiel: 
Deixei o meu tamborim no sereno

Orvalho da madrugada molhou

Sei que está chegando a hora

A lua está me esperando

Sem meu tamborim não vou

Sei que estou fazendo falta

No meio da batucada

Só porque não vou sambar

[...].

(“Sem meu tamborim não vou”, Armando Marçal e J. Portela, I943).

Relevância e prestígio conferidos ao sambista pela perícia rítmica derivam da função agregadora que a percussão desempenha na realização da música em grupo e da festa comunitária. Muito diverso é o sentido atribuído ao violão, instrumento que serve ao acompanhamento da voz mas também à execução melódica, num ambiente mais íntimo e personalizado. Em oposição ao movimento coletivo e ao apelo coreográfico da percussão, o violão está presente no âmbito do canto solo, na expressão individual, na exposição da alma que reflete, divaga e sonha. Integrou a linguagem da modinha e da seresta. Não por acaso, os conselhos que Noel dirige ao "Rapaz folgado" situam o violão no polo oposto ao da malandragem, associando-o ao sentimento e à escrita poética que produzem o samba-canção:

Da polícia quero que escapes

Fazendo samba-canção

Eu já lhe dei papel e lápis

Arranje um amor e um violão.

Mais adiante, na bossa-nova, o instrumento ganhará novas conotações, mais leves e menos sombrias, mas sempre ligadas ao âmbito da subjetividade.

Participando da história poética dessa imagem persistente na letrística da música popular, o violão aparece em vários sambas de Bide e Marçal como companheiro do sujeito solitário, confidente e alterego que se manifesta na alegria e na dor, no som e no silêncio.
A primeira vez
Que eu te encontrei
Alimentei a ilusão de ser feliz
Eu era triste sorri
Peguei no pinho e cantei
Muitos versos eu fiz
Em meu peito guardei
Um dia você partiu
Meu pinho emudeceu 
E a minha voz na garganta morreu

[...].

(“A primeira vez”, Bide e Marçal, I940).

Violão amigo ouve os meus ais

Hoje os meus segredos não suporto mais

Talvez tu compreendas meu sentir

Quero exprimir neste samba o tanto que sofri

Quem de mim sorriu por certo há de chorar

Quando ouvir alguém cantar

[...].

(“Violão amigo”, Bide e Marçal, I942).

[...]

Fico nas cordas do pinho

Dizendo tudo o que sinto

Meu companheiro dileto

Sabe que eu falo e não minto

Ele é o meu consolo, é quem chora comigo

Mora na minha choupana e ouve o que eu digo

[...].

(“Companheiro dileto”, Bide e Marçal, I936).

Entretanto, nos arranjos instrumentais das primeiras gravações destes e de outros sambas, o violão tem função secundária em relação ao protagonismo dos sopros (principalmente a flauta) e da percussão. Ou seja, o que se encena na letra não se deixa ouvir no som musical. Mais uma vez, aqui se entrelaçam sugestões dissonantes entre os diferentes estratos que compõem a canção.

\section{ConClusão}

A ambivalência de dor e prazer deriva de uma estrutura complexa. No mesmo fonograma, os diversos elementos que constituem o conjunto da obra-canção podem atuar de modos variados e até contrastantes, que todavia se harmonizam aos ouvidos habituados do público. Quando a escuta crítica se faz inclusiva, capaz de transitar entre a análise e a síntese, percebe que as aparentes dicotomias ou paradoxos não se fundam sobre bases apartadas e estanques, mas movem-se num espaço pleno de sugestões dinâmicas.

A impressão de uma "alegria paradoxal" que o samba provoca em nossos ouvidos de "estrangeiros", e que tentamos compreender e relatar mediante noções técnicas e teóricas, é característica de uma recepção crítica ilustrada. É um "problema" para os pesquisadores, não para os sambistas ou para a grande comunidade que nos acostumamos a chamar de "mundo do samba". O problema nos impele às tarefas intelectuais da observação, da investigação, e daí brotam resultados decerto 
aceitáveis. Por exemplo, é possível ver nessa conjugação de alegria e tristeza analogias com os gestos e situações de resistência e conformismo praticados ou experimentados pelos grupos étnicos e sociais carentes e oprimidos. Mas, tanto pela via contextual e sociológica quanto pela via da análise intrínseca, a "explicação" que mal ou bem logramos produzir daquele estranho objeto - o tal "mistério do samba" - sempre soa incompleta ou insatisfatória face ao poder que o próprio objeto exala e guarda. A simplicidade aparentemente padronizada e estável do objeto é na verdade movida por uma força que extrapola os sentidos e determinações históricas, porque está no campo da poesia: a poesia que Paul Zumthor (2000, p. I5) define como "uma arte da linguagem humana, independente de seus modos de concretização e fundamentada nas estruturas antropológicas mais profundas”.

O profundamente humano é a matéria e a energia do poético em suas muitas formas. Não se trata de qualquer imagem mítica do samba, mas sim da fantástica elaboração da sua linguagem tão peculiar e tão compartilhada, cujo poder (como o de outras formas verbo-voco-musicais) age simultaneamente sobre tudo o que é o ser humano, em corpo e alma. O corpo, que canta e dança, é talvez a dimensão que se presta mais imediatamente ao convívio e à interação. A alma é onde o sujeito pode se isolar, se esconder, experimentando o estar só. Mais ou menos como dizia Manuel Bandeira (I974, p. I56) em "Arte de amar":

As almas são incomunicáveis.

Deixa o teu corpo entender-se com outro corpo.

Porque os corpos se entendem, mas as almas não.

Agora, voltemos à hipótese inicial sobre a união de letras tristes com músicas alegres. Luiz Tatit ensinou que a arte do cancionista consiste em "equilibrar [com aparente naturalidade] a melodia no texto e o texto na melodia" (TATIT, I996, p. 9). Sua teoria da canção oferece bons dispositivos analíticos para observar a articulação entre os percursos linguístico e musical, a partir dos quais o autor delineia duas vertentes básicas da linguagem cancional popular. Numa delas predominam as tensões passionais, destacando os gestos amplos do perfil melódico, a sustentação das notas, o andamento reduzido e o ritmo amortecido, entre outros efeitos coerentes com uma postura contemplativa e interiorizada. Na outra predominam as tensões temáticas, investindo na articulação e pulsação das notas, privilegiando o ritmo, a percussão, a reiteração melódica e linguística, os impulsos somáticos exteriorizados, o convite à participação física. O samba-canção afina-se com a linguagem da passionalização, o samba sincopado com a linguagem da tematização.

O repertório aqui examinado mistura traços das duas dicções, realizando uma possibilidade apontada pelo próprio Tatit (I996): essas linguagens não são estanques, e sim intercomunicáveis, com mais ou menos manifestação dos traços de uma e de outra. Usada com a maleabilidade indicada pelo autor, a classificação nos ajuda a compreender o formato compósito dos sambas de Bide e Marçal, com seus cruzamentos entre interioridade e exterioridade, estado anímico e ação corporal.

Finalmente, pode-se observar uma analogia entre o processo constitutivo desse formato e o que se deu na linguagem do lundu, antepassado direto do samba: 
O lundu-dança seria apoiado em estribilhos curtos, eventualmente intercalados por chulas, sempre estivera fora dos salões. Ao contrário, o lundu-canção "sofisticou" sua estrutura aparentando-se à modinha erudita, sem deixar de lado o exotismo atribuído ao lundu-dança. (LIMA, 20I3, p. I26).

O amálgama do tônus dançante da música (assegurado pelo andamento, pela energia rítmica ou pela interpretação jocosa do cantor) com o tônus emocional da letra (e às vezes também de certos traços melódicos, vocais e instrumentais) é o que move esses sambas. Neles o sujeito se encontra com as penas da vida, aquelas que traz dentro de si, mas também com a vida da comunidade à qual ele pertence e para cuja festa contribui com o que sabe sentir e fazer: o canto, o batuque, a arte do sambista. A história e o sujeito estão inteiros ali, em contraponto justo e verdadeiro, porque o samba que é "dono do corpo" é o mesmo que "nasce no coração"s.

\section{SOBRE A AUTORA}

CLAUDIA NEIVA DE MATOS é professora doutora no Programa de Pós-graduação em Estudos de Literatura da Universidade Federal Fluminense (UFF) e vicepresidente (20I6-20I8) da Seção Latino-Americana da International Association for Study of Popular Music (IASPM-AL).

E-mail: laparole@terra.com.br

\section{REFERÊNCIAS ${ }^{16}$}

ACADEMIA DO SAMBA. Marçal. Disponível em: <academiadosamba.com.br/memoriasamba/bambas/ 04-marcal.htm>. Acesso em: Io out. 2017.

ANDRADE, Mário. Macunaíma: o herói sem nenhum caráter. São Paulo: Martins, I973.

ANDRADE, Oswald de. Manifesto antropófago. In: TELES, Gilberto Mendonça. Vanguarda europeia $e$ modernismo brasileiro: apresentação e crítica dos principais manifestos vanguardistas. Petrópolis: Vozes; Brasília: INL, I976.

BANDEIRA, Manuel. Antologia poética. Rio de Janeiro: José Olympio, I974.

BARCELOS, Tânia Maia. Subjetividade e samba: a dor pede passagem. Psicologia em Revista, v. I6, n. I, Belo Horizonte, abril 2010.

I5 Alusões ao título de um livro de Muniz Sodré (Samba: o dono do corpo) e ao último verso de "Feitio de oração", de Noel Rosa e Vadico.

I6 LPs e CDs constantes desta relação contêm material iconográfico e textual escrito ou falado (depoimentos) citados no trabalho. 
BIDE, Marçal e o Estácio. LP. Texto do encarte. Coleção História da Música Popular Brasileira. Abril Cultural, I979.

BILAC, Olavo. Música brasileira. In: . Tarde. Rio de Janeiro/São Paulo/Belo Horizonte: Livraria Francisco Alves, I9I9, p. I8-I9. Ex-libris José Mindlin. Disponível em: <digital.bbm.usp.br/bitstream/ bbm/454I/I/002927_COMPLETO.pdf >. Acesso em: jun. 2018.

BORGES, Beatriz. Samba-canção: fratura e paixão. Rio de Janeiro: Codecri, I982.

EFEGÊ, Jota. Figuras e coisas da música popular brasileira. V. I. Rio de Janeiro: Funarte, I978.

LIMA, Ari Do samba carioca urbano e industrial ao samba nacional e mestiço. ArtCultura, v. I5, n. 26, Uberlândia, jan.jun. 2013.

LISTA de discussões da International Association for Studies of Popular Music, Seção Latino-americana.

Disponível em: <Iaspm-al@googlegroups.com>. Acesso em: Io nov. 2017.

MARÇAL, Nilton. Marçal interpreta Bide e Marçal. LP. EMI-Odeon, I978.

. Mestre Marçal. CD. Coleção A música brasileira deste século por seus autores e intérpretes. São Paulo: Sesc, 2000. Gravação original realizada em 9/3/199I para o programa Ensaio, TV Cultura de São Paulo.

MATOS, Cláudia Neiva de. O malandro no samba: uma linguagem na fronteira. Tese (Mestrado em Letras).

Pontifícia Universidade Católica do Rio de Janeiro, I98I. . Acertei no milhar: samba e malandragem no tempo de Getúlio. Rio de Janeiro: Paz e Terra, I982.

PRADO, Paulo. Retrato do Brasil: ensaio sobre a tristeza brasileira. São Paulo: Ibrasa; Brasília: INL, I98I.

MORAES, Renato de. Encarte do LP Bide Marçal e o Estácio. Abril Cultural, I979. (História da Música Popular Brasileira).

SEVERIANO, Jairo; MELLO, Zuza Homem de. A canção no tempo: 85 anos de músicas brasileiras. V. I: I9OII957. São Paulo: Editora 34, I997.

TATIT, Luiz. O cancionista: composição de canções no Brasil. São Paulo: Edusp, I996.

ULHÔA, Martha Tupinambá de. Estilo e emoção na canção - notas para uma estética da música brasileira popular. Cadernos de Estudo - Análise Musical. São Paulo; Belo Horizonte: Atravez, v. 8/9, I995, p. 30-4I. Disponível em: $<$ http://www4.unirio.br/mpb/ulhoatextos/Estilo_e_emocao_na_cancao_Versao_online.pdf $>$. Acesso em: I7 set. 2017.

VILLAÇA, Túlio Ceci. O samba é o pai do prazer, o samba é o filho da dor. Sobre a canção e seu entorno e o que ela pode se tornar. Disponível em: <https://tuliovillaca.wordpress.com/20II/Io/I4/o-samba -e-o-pai-do-prazer-o-samba-e-o-filho-da-dor $>$. Acesso em: 2 out. 2017.

ZUMTHOR, Paul. Performance, recepção, leitura. São Paulo: Educ, 2000. 